\title{
Culture And Religion Value in E-English Textbook for Junior High School: A Content Analysis
}

\author{
Nurul Lailatul Khusniyah ${ }^{1}$, dan Indah Khomsiyah ${ }^{2}$ \\ ${ }^{1}$ Universitas Islam Negeri Mataram, Nusa Tenggara Barat, Indonesia \\ 2Institut Agama Islam Negeri Tulungagung, Jawa Timur, Indonesia \\ email:1nurullaila@uinmataram.ac.id
}

\begin{tabular}{|c|c|c|}
\hline \multicolumn{3}{|c|}{$\begin{array}{l}\text { The aim of this study is to know the culture and religion value contains in an English } \\
\text { textbook for junior high school. Culture and religion have integrated into each utterance } \\
\text { that is in the textbook. The study used the qualitative approach through a content } \\
\text { analysis method. The procedure value analysis used Byram's theory. Data were taken } \\
\text { from an utterance in each chapter. The result of the data analysis found that belief and } \\
\text { behaviour have } 22,8 \% \text {, socialization and life cycle has } 60 \% \text {, stereotypes and national } \\
\text { identity has } 11,4 \% \text {, and Social and political institution has } 5,8 \% \text {. The value that } \\
\text { dominates in the textbook is socialization and life cycle. The material in the textbook } \\
\text { concern to a local and simple concept. }\end{array}$} \\
\hline \multicolumn{3}{|c|}{ Keywords: Culture, English, Religion, Textbook, Value. } \\
\hline $\begin{array}{c}\text { First Receive: } \\
3 \text { Maret } 2019\end{array}$ & $\begin{array}{c}\text { Revised: } \\
17 \text { April } 2019\end{array}$ & $\begin{array}{l}\text { Accepted: } \\
5 \text { Mei } 2019\end{array}$ \\
\hline $\begin{array}{c}\text { Final Proof Recieved: } \\
\text { 10 Juni } 2019\end{array}$ & \multicolumn{2}{|c|}{$\begin{array}{l}\text { Published: } \\
\text { 21 Juni } 2019\end{array}$} \\
\hline $\begin{array}{r}\text { Khusniyah, N. L., \& Kho } \\
\text { Textbook For Jur }\end{array}$ & $\begin{array}{l}\text { ite (in APA sty } \\
\text { 19). Culture A }\end{array}$ & $\begin{array}{l}\text { in E-English } \\
8(1), 15-24 .\end{array}$ \\
\hline
\end{tabular}

\section{INTRODUCTION}

The textbook has the main role in teaching and learning process like as English language teaching-learning process in the classroom. It is sources of information and an effective tool to improve students' learning experience and ability. So, the teachers have to use an appropriate textbook that is able to full learners' needs in English learning. In era digital, students and teachers can access the textbook using the internet network, like an ebook. Nowadays, our government has published Electronic School Book is known Buku Sekolah Elektronike (BSE) which can get in a form of electronic. Then, the lack of nationally textbook is fulfilled. Because the price of the textbook usually is too expensive. The e-book is as media of learning can support the process of learning in the classroom. It is like a print book. It's appropriate with Cunningsworth's suggest that textbooks are the source for achieving predetermined goals and objectives as the students' needs. ${ }^{32}$ It means that the textbook is used to get the success of learning in the class. So, it gave the changing of process learning ways. The student is able to get all the knowledge. As it is known in Crawford that

\footnotetext{
32 Cunningsworth, Alan. 1995. Choosing Your Coursebook. Heineman: Oxford
} 
Nurul Lailatul K. \& Indah K., Culture And Religion Value In E-English Textbook For Junior High School:...

textbook is as a possible agent for change. ${ }^{33}$ Therefore, the textbook has 3 elements to assess, namely comprehensibility, curriculum, and instruction. ${ }^{34}$

Brophy's research that has examined how to teach using textbooks in elementary schools in the United States, discovered that elementary school teachers did not teach strictly by their textbooks. Instead, they adapted the particular curriculum to the needs of their students. In particular, experienced teachers, who are comfortable in their knowledge of the subject matter Mei feel confident it will not be available to the less experienced teachers who Mei then depend heavily on the textbook for guidance(Ramazani, 2013). ${ }^{35}$ Thus, the textbook can be used by the teacher to help the students in the class. It is as media effective to deliver knowledge.

The content of the textbook must be understood comprehensive, so the values that want to teach are able to attach the students. Besides that, it has relevance with the purposes which is in the curriculum and syllabus. Of course, it is harmony with the instruction process. Because the English textbook for Junior High School is able to guide on a good character and a good textbook contains some character education value as building process of soft skills learning. Each content has some value that builds students' character education. One of the character education values is religion and culture social value. Some research had done to explore these values in the English material. Ramjzoo has compared two textbooks. In his result research concluded that international textbooks have relevance in principles of communication with the local culture. ${ }^{36}$ Other research from Cheng \& Beigi shows that textbooks were also analyzed to determine whether the propagation of religious content was overt or covert. Finally, the impact of religious content in textbooks was discussed with reference to identity and nation-building. ${ }^{37}$

Textbooks are cultural artefacts developed by authors with their own cultural assumptions and biases. The topical and linguistic contents of the books are necessarily engulfed in the cultural structures. The cultural density in such books is suggestive of the

\footnotetext{
${ }^{33}$ Crawford, Jane. 2003. The Role of Material in Language Classroom: Finding the Balance, Methodology in Language Teaching, ed,. Jack C. Richard and Willy A. Renandya. New York: Cambridge University press

${ }^{34}$ Chambliss dan Coffee. 1998. Textbooks for Learning. New Jersey: Blackwell Publisher.

35 Ramazani, M. 2013. Teachers' Perceptions of Using English Textbooks for Iranian Technical and Vocational College Students. Procedia - Social and Behavioral Sciences, 70, 1748-1762. https://doi.org/10.1016/J.SBSPRO.2013.01.250

${ }^{36}$ Ramjzoo, Rob. High school or Private Institutes Textbook, which fulfil Communicative Language Teaching in the Iranian Context Thesis. The Asian EFL Journal. 2008. pp.126-130

${ }^{37}$ Cheng, K. K. Y., \& Beigi, A. B. (2012). Education and religion in Iran: The inclusiveness of EFL (English as a Foreign Language) textbooks. International Journal of Educational Development, 32(2), 310-315. https://doi.org/10.1016/J.IJEDUDEV.2011.05.006
}

Copyright (C) 2019 Schemata Journal

Available online at http://journal.uinmataram.ac.id/index.php/schemata 
Nurul Lailatul K. \& Indah K., Culture And Religion V alue In E-English Textbook For Junior High School:..

tacit goal that foreign language learners need to get acculturated to the target language culture if learning is to be achieved. The analysis Zarei \& Khalessi showed that value as one component comprised 'entertainment, liberal, consumerism, and inculcation of Western values'. Norm as another component encompassed 'girlfriend-boyfriend relationship, opposite-sex contact or dating, pet-keeping, and club-dancing'. The next category, the i.e., institution involved 'entertainment, commercial, sports, educational, and conventional institutions'. The ten sub-components of cultural artefact included 'occupation, clothes, name, music, sport, art, celebrity, food, instrument, and education. Overall, the results indicate that textbooks are artefacts which are strongly grounded in cultural assumptions and biases. $^{38}$

Students in Junior High School learn English are four skills. These are speaking, listening, reading and writing. The textbook has some text and dialogue which is completed with the exercise. In each utterance that used both text or exercise has value to teach character education like as culture and religion. So, the student will not only get information to improve their knowledge but also they learn good character value to prepare students as a quality human with a good attitude. It has a harmony concept between hard skills, technique skills, and soft skills. While we know that Junior High School is the transition period for students from the child to adult. It is a critic period, if they never receive a good guide from the character and religion value, the impact will show in their result of an act in each situation. To answer the problem and challenge that faced the digital era and easy period to access everything is very important to build good students' character. Then, this study concern to explore the culture and religion value that is in the English language material for Junior High School.

\section{RESEARCH METHOD}

This research uses a qualitative approach using content analysis methods. The content analysis implemented as a method to explore the culture and religion values that are in the English textbook is used in the Junior High School at grade VII, VIII, and IX. So, the study got information some value was appropriate with the character education, referred to culture value and religion. The sample of the book is namely; 1) Bahasa Inggris When English

38 Zarei, G. R., \& Khalessi, M. (2011). Cultural load in English language textbooks: An analysis of interchange series. Procedia - Social and Behavioral Sciences, 15, 294-301. https://doi.org/10.1016/J.SBSPRO.2011.03.089 
Nurul Lailatul K. \& Indah K., Culture And Religion V alue In E-English Textbook For Junior High School:...

Rings a Bell SMP/MTs Kelas VII, 2) Bahasa Inggris When English Rings a Bell SMP/MTs Kelas VIII, and 3) Bahasa Inggris Think Globally Act Locally SMP/Mts Kelas IX. The publisher is the Ministry of National Education. The study used Byram's theory to know these values. There are four elements the checklist content, they are belief and behaviour, socialization and life cycle, stereotypes and national identity, and social and political institution. ${ }^{39}$ The process of collecting data is taken from the documentation, and organize the theme and content that has culture and religion values. Validity techniques include serious reading, checking, and intensifying data analysis and confirmed in (confirmability) with experts who are competent according to the object of study in research and peers or (triangulation of sources).

\section{FINDING AND DISCUSSION}

The process of analysis has some steps as a content analysis procedure. There are 3 textbooks that are taken form grade VII, VIII, and IX. The process identifies the value that refers to Byram's theory. These values are taken as comprehensive from each chapter. Based on the analysis data process, here is the result of recapitulation data;

Table 1. The Category of Culture and Religion Values

\begin{tabular}{|l|c|c|c|c|}
\hline \multirow{2}{*}{ Grade Book } & \multicolumn{4}{|c|}{ Category } \\
\cline { 2 - 5 } & $\begin{array}{r}\text { Belief and } \\
\text { Behaviour }\end{array}$ & $\begin{array}{c}\text { Socialization } \\
\text { and life cycle }\end{array}$ & $\begin{array}{c}\text { Stereotypes } \\
\text { and national } \\
\text { identity }\end{array}$ & $\begin{array}{c}\text { Social and } \\
\text { political } \\
\text { institution }\end{array}$ \\
\hline $\begin{array}{l}\text { Bahasa Inggris When English } \\
\text { Rings a Bell SMP/MTs Kelas VII }\end{array}$ & 2 & 4 & 2 & 0 \\
\hline $\begin{array}{l}\text { Bahasa Inggris When English } \\
\text { Rings a Bell SMP/MTs Kelas } \\
\text { VIII }\end{array}$ & 4 & 9 & 0 & 0 \\
\hline $\begin{array}{l}\text { Bahasa Inggris Think Globally } \\
\text { Act Locally SMP/Mts Kelas IX. }\end{array}$ & 2 & & & 2 \\
\hline Total & 8 & 21 & 4 & 2 \\
\hline
\end{tabular}

39 Byram, M, Language and Culture: The Need for Integration. In M. Byram (ed.), Germany, Its representation in textbook for teaching German in Great Britain Germany, Frankfurt am Main: Diesterweg, pp. 3-16, (1993) 
Nurul Lailatul K. \& Indah K., Culture And Religion V alue In E-English Textbook For Junior High School...

Table 1 shows the account of culture and religion values which is in the English textbook for Junior High School. In all grade, it knows that the socialization and life cycle have the highest value. These textbooks tried to build the character value related to real life. Belief and behaviour have 22,8\%, socialization and life cycle has $60 \%$, stereotypes and national identity has $11,4 \%$, and Social and political institution has $5,8 \%$. It can be concluded that the highest category is socialization and life cycle. From the four categories can be known as an integrated value that is in the culture and religion value. These help the student to build the character.

The first is belief and behaviour. The belief contained in the English textbook for junior high school students teaches them to be someone who has confidence in the actions that must be taken. This means that they must be able to determine what is right and wrong. This can be reflected in the attitudes and behaviours that arise in each action. Belief can be used to make decisions, we are assuming the causal relationships of the past, which led to the belief, will also apply in the future. In a rapidly changing world where complexity is increasing day by day, using information from the past to make decisions about the future Mei not be the best way to support us in meeting our needs. It can be concluded that belief is a part of religion value that can be developed in the textbook content. These books have a good design and setting the content of materials in English learning to delivery the religion system. They packed it in text and dialogue of daily life. So, it is a benefit system to be a success in the learning process.

The second is the socialization and life cycle. It related to the ways of human to do their life. The student has taught the process of socialization in society and the ways are to make the relationship. While in stereotypes and national identity refers to the process of the identities of people. The material in these books present the differences between people from Indonesia. It has taught the nationality soul to each student. The last social and political institution has taught the way to give caring for each other.

Many researchers has proved to evaluate the textbook. Tan, Mahadir Naidu, \& Jamil@Osman has identified the dominant moral values of a good citizen that are conveyed by Malaysian moral education textbooks. ${ }^{40}$ The findings demonstrate that 'responsibility' is the dominant value for shaping a good citizen in Malaysia. The value of responsibility in the

40 Tan, B. P., Mahadir Naidu, N. B., \& Jamil@Osman, Z. (2018). Moral values and good citizens in a multi-ethnic society: A content analysis of moral education textbooks in Malaysia. The Journal of Social Studies Research, 42(2), 119-134. https://doi.org/10.1016/J.JSSR.2017.05.004 
Nurul Lailatul K. \& Indah K., Culture And Religion V alue In E-English Textbook For Junior High School:.. textbooks embraces not only the meanings of self-obligation and accountability, but responsibility is also defined as an individual's sense of self-discipline in their behaviour that enables them to avoid conflict and strive for harmonious social order. The other important values are "Respect", "Helpful", "Hard-working" and "Caring". This study provides an example of how a multi-ethnic nation state like Malaysia promotes these moral values through its educational curriculum, for political legitimacy and forging national unity.

Other research is evidenced by Behnam, Mozaheb. ${ }^{41}$ The findings of this study demonstrated that religion is an integral part of Iranian EFL textbooks, which is taught indirectly. Additionally, Iranian EFL textbooks promote Islamic notions and ideology regarding theocratic countries. Moral implicature is not the concern of this study however, the main focus of this study is the change in the Western viewpoint of inclusiveness while looking at a theocratic setting i.e., Iran. Additionally, the researchers of the present study suggest that it is important to promote the sense of nationhood in EFL textbooks among members of theocratic countries.

These English textbooks intended to a local value. The culture has given the concept of belief, attitude, behaviour, spiritual and lifestyle. So, the cultural value in these books has included religion value. The belief (religion) and culture have an important role. It shows in every instruction of learning in the textbooks. The Indonesian government has designed English textbooks that are equipped with values such as complete cultural values and religious values. So that the government's goal in building graduates with good character can be achieved. Therefore, the material presented is also in accordance with current needs and is directly related to real life. If it is understood more deeply that the English textbook for junior high school students that has been designed by the Indonesian government bookkeeping agency also presents the concept of contextual learning. The combination of cultural values and religion unites into meaningful unity. It can be showed in each utterance in the textbook through the informative capacities.

\section{CONCLUSION}

The result of analysis shown that the dominant of values is socialization and life cycle and the second is belief and behaviour. It presented the simple material and authentic. Each utterance in this textbook has difference value that taught the students as a good

41 Behman, Biook, Mohammad Amin Mozaheb. 2013. Identity, Religion and New Definition of Onclusiveness in Iranian High School EFL Textbooks. Procedia - Social and Behavioral Sciences 70, pp. 1099 - 1108

\section{Copyright (C) 2019 Schemata Journal}

Available online at http://journal.uinmataram.ac.id/index.php/schemata 
Nurul Lailatul K. \& Indah K., Culture And Religion V alue In E-English Textbook For Junior High School:..

human. Thus, the textbook has reflected the objectives and purposes in the curriculum. The finding suggests that the government has to create comparing of culture between Indonesia and Western.

\section{REFERENCES}

Byram, M, 1993. Language and Culture: The Need for Integration. In M. Byram (ed.), Germany, Its representation in textbook for teaching German in Great Britain Germany, Frankfurt am Main: Diesterweg, pp. 3-16

Behman, Biook, Mohammad Amin Mozaheb. 2013. Identity, Religion and New Definition of Onclusiveness in Iranian High School EFL Textbooks. Procedia - Social and Behavioral Sciences 70, pp. $1099-1108$

Cunningsworth, Alan. 1995. Choosing Your Coursebook. Heineman: Oxford

Crawford, Jane. 2003. The Role of Material in Language Classroom: Finding the Balance, Methodology in Language Teaching, ed,. Jack C. Richard and Willy A. Renandya. New York: Cambridge University press

Cheng, K. K. Y., \& Beigi, A. B. 2012. Education and religion in Iran: The inclusiveness of EFL (English as a Foreign Language) textbooks. International Journal of Educational Development, 32(2), 310-315. https://doi.org/10.1016/J.IJEDUDEV.2011.05.006

Chambliss dan Coffee. 1998. Textbooks for Learning. New Jersey: Blackwell Publisher.

Ramazani, M. 2013. Teachers' Perceptions of Using English Textbooks for Iranian Technical and Vocational College Students. Procedia - Social and Behavioral Sciences, 70, 1748-1762. https://doi.org/10.1016/J.SBSPRO.2013.01.250

Ramjzoo, Rob. 2008. High school or Private Institutes Textbook, which fulfil Communicative Language Teaching in the Iranian Context Thesis. The Asian EFL Journal. pp.126-130

Tan, B. P., Mahadir Naidu, N. B., \& Jamil@Osman, Z. (2018). Moral values and good citizens in a multi-ethnic society: A content analysis of moral education textbooks in Malaysia. The Journal of Social Studies Research, 42(2), 119-134. https://doi.org/10.1016/J.JSSR.2017.05.004

Zarei, G. R., \& Khalessi, M. (2011). Cultural load in English language textbooks: An analysis of interchange series. Procedia - Social and Behavioral Sciences, 15, 294-301. https://doi.org/10.1016/J.SBSPRO.2011.03.089

\section{APPENDICES}

Recapitulation of Culture and Religion Value from Textbook Class VII

\begin{tabular}{|c|l|l|}
\hline No & \multicolumn{1}{|c|}{ Content } & \multicolumn{1}{c|}{ Category } \\
\hline 1 & Good morning. How are You? & Belief and Behaviour \\
\hline 2 & It's Me & Stereotypes and national identity \\
\hline 3 & What Time Is It? & Socialization and life cycle \\
\hline 4 & This is My World & Socialization and life cycle \\
\hline 5 & It's a beautiful day! & Socialization and life cycle \\
\hline 6 & We love what we do & Socialization and life cycle \\
\hline
\end{tabular}

Copyright $\odot 2019$ Schemata Journal

Available online at $\mathrm{http}: / /$ journal.uinmataram.ac.id/index.php/schemata 
Nurul Lailatul K. \& Indah K., Culture And Religion V alue In E-English Textbook For Junior High School...

\begin{tabular}{|l|l|l|}
\hline 7 & I'm Proud of Indonesia! & Stereotypes and national identity \\
\hline 8 & That's what friends are supposed to do & Belief and Behaviour \\
\hline
\end{tabular}

Recapitulation of Culture and Religion Value from Textbook Class VIII

\begin{tabular}{|c|l|l|}
\hline No & \multicolumn{1}{|c|}{ Content } & \multicolumn{1}{c|}{ Category } \\
\hline 1 & It's English time! .... & Socialization and life cycle \\
\hline 2 & We can do it, and we will do it .... & Belief and Behaviour \\
\hline 3 & We know what to do .... & Belief and Behaviour \\
\hline 4 & Come to my birthday, please! .... & Socialization and life cycle \\
\hline 5 & I'm so happy for you! .... & Socialization and life cycle \\
\hline 6 & Our busy roads ... & Socialization and life cycle \\
\hline 7 & My uncle is a zookeeper ... & Socialization and life cycle \\
\hline 8 & What are you doing? .... & Socialization and life cycle \\
\hline 9 & Bigger is not always better ... & Socialization and life cycle \\
\hline 10 & When I was a child .. & Belief and Behaviour \\
\hline 11 & Yes, we made it! .. & Belief and Behaviour \\
\hline 12 & Don't forget it, please! .... & Socialization and life cycle \\
\hline 13 & We got a lot of histories .... & Socialization and life cycle \\
\hline
\end{tabular}

Recapitulation of Culture and Religion Value from Textbook Class IX

\begin{tabular}{|c|l|l|}
\hline No & \multicolumn{1}{|c|}{ Content } & \multicolumn{1}{|c|}{ Category } \\
\hline 1 & Congratulations! & Belief and Behaviour \\
\hline 2 & Let's start our wall magazines! & Socialization and life cycle \\
\hline 3 & What should I do that for? & Belief and Behaviour \\
\hline 4 & Be healthy, be happy & Socialization and life cycle \\
\hline 5 & This is how you do it & Socialization and life cycle \\
\hline 6 & $\begin{array}{l}\text { Everybody is always in the middle of } \\
\text { something }\end{array}$ & Social (caring) and political institution \\
\hline 7 & What will be will be & Social (caring) \\
\hline 8 & $\begin{array}{l}\text { We have been to an orphan home } \\
\text { We went there last Sunday }\end{array}$ & Socialization and life cycle \\
\hline 9 & You get what you earn! & Socialization and life cycle \\
\hline 10 & Sangkuriang & Stereotypes and national identity \\
\hline 11 & They are made in Indonesia & Stereotypes and national identity \\
\hline 12 & What is it? & Socialization and life cycle \\
\hline 13 & Come and visit us! & Socialization and life cycle \\
\hline 14 & You can always come back home & Socialization and life cycle \\
\hline
\end{tabular}

